Article

\title{
An Exploration of Content and Drivers of Online Sustainability Disclosure: A Study of Italian Organisations
}

\author{
Matteo Mura ${ }^{1,+}$, Mariolina Longo ${ }^{1,+}$, Ana Rita Domingues ${ }^{2,3, *,+}$ 迥 and Sara Zanni ${ }^{1,+}$ \\ 1 Department of Management, University of Bologna, Via Terracini 28, 40131 Bologna, Italy; \\ matteo.mura@unibo.it (M.M.); mariolina.longo@unibo.it (M.L.); sara.zanni7@unibo.it (S.Z.) \\ 2 Department of Management, University of Bologna, Via Capo di Lucca 34, 40126 Bologna, Italy \\ 3 CENSE-Center for Environmental and Sustainability Research, NOVA School of Science and Technology, \\ NOVA University Lisbon, 2829-516 Caparica, Portugal \\ * Correspondence: anarita.domingues@unibo.it \\ + These authors contributed equally to this work.
}

Received: 1 May 2019; Accepted: 18 June 2019; Published: 21 June 2019

\begin{abstract}
Organisations have been disclosing environmental and social information through different tools, including their websites. However, the type of environmental and social information that organisations disclose online, and what are the characteristics of those organisations is still not fully understood. This research aims to (a) identify which environmental and social information organisations disclose online; and (ii) explore drivers of the specific information disclosed. We collected data on sustainability disclosures from 2008 Italian organisations. Results show that overall the amount of environmental and social information disclosed online is low. However, organisational characteristics explain different contents of disclosure. Bigger organisations (in terms of revenues and number of employees), and with environmental and social certifications in place tend to disclose more environmental and social information. Also, consumer goods' organisations disclose mostly information related to the supply chain; whilst resource-intensive industries disclose mostly information on corporate social responsibility. This research shows that overall there is still a reserved attitude towards disclosing environmental and social information in Italian organisations, providing little information to stakeholders about environmental and social policies, strategies and practices. This study provides researchers and practitioners information on the content of sustainability information disclosed and possible drivers for their disclosure; this supports their understanding of the conditions where voluntary sustainability disclosure is more expected.
\end{abstract}

Keywords: business sustainability; sustainability indicators; environmental and social disclosure; intangible assets

\section{Introduction}

Organisations have been reporting their environmental and social performance through different tools, such as social and environmental reports and sustainability reports. These have had considerable development over the few last years, in spite of having started as a voluntary practice [1]. The emergence of sustainability guidelines and frameworks have guided organisations to report sustainability-related information using different metrics, as different reporting bodies have proposed their own set. For instance, Global Reporting Initiative (GRI), Global Compact, Asset4, and CDP propose guidelines for reporting organisation's sustainability performance. Many organisations cherry-pick indicators from different guidelines and frameworks which turns out in a fragmentary evaluation of sustainability-related performance and in a variety of reports that are not necessarily comparable [2,3]. Despite the emergence 
of new regulations, namely at the European level [4], the decision to disclose, how to disclose, and the type of sustainability-related aspects to be disclosed are still mainly a voluntary practice, especially for Small and Medium Enterprises (SMEs). These organisations are considered to have potentially less significant impacts than larger organisations and are indeed out of the scope of the emergent regulation on disclosure of sustainability information.

Besides the traditional formal reporting schemes, organisations are currently using a broader variety of communication channels to disclose environmental and social information, such as traditional news media [5], and social media [6]. Internet-based communication technologies offer significant benefits for organisations and stakeholders as they provide: (a) detailed supplementary information consistent with the information present in the organisation's sustainability report; (ii) a platform to analyse and respond to stakeholders' information requests (increasing the interaction with stakeholders beyond the traditional one-way communication channels); and (iii) access to data, search engines, and analytical tools [6,7]. Opposite to formal reporting, this type of communication is designed towards a broader spectrum of readers, which possibly enhances the number of stakeholder groups for whom the information may be assessed. The measurement system needs to be flexible enough to adjust to different requirements of information [8]. Thus, many times information available is not as detailed as the one present in formal reports. Stakeholders can potentially choose the information they are most interested in based on their preferences, decreasing information overload and enhancing ongoing communication, constructive dialogue and future engagement initiatives [9]. Web-based tools and social media have the potential to drive stakeholder engagement and relationship development [6] as it can increase dialogues, and consequently support the definition of material issues for stakeholders and relevant information [10].

Different drivers motivate organisations to voluntarily communicate non-financial information. These can be characterised in external drivers based on legitimacy [11-14] and institutional pressures as organisations from the same industry adopt sustainability reporting e.g., [15]; (ii) internal drivers based on assessing the sustainability efforts of the organisation [2,16,17]; or (iii) a combination of internal and external factors [16]. This approach is mirrored into two main groups of theories, used by researchers to explain their findings, particularly socio-political theories that focus on seeking legitimacy in the external context of the organisation and managerial theories that focus on internal factors of governance [18].

This research uses a multi-theoretical framework to explore possible drivers on the disclosure of sustainability information, in particular legitimacy theory [19], and neo-institutional theory [20]. These two theories have been exploited by similar studies. In particular, the former has been applied to explore the drivers of environmental disclosure by large organisations [21], the communication of Corporate Social Responsibility (CSR) by a specific sector [22], and the content and extent of social and environmental disclosure on the web by listed companies [23]; the latter supported the investigation on the association between environmental disclosure quality and industry membership [24]. Both theories, involving social and institutional characteristics, are complementary to explain content and drivers of environmental and social disclosure by organisations. The social and institutional context may influence the adoption of environmental strategies by organisations in order to gain corporate benefits, such as being seen as a responsible organisation, and gain reputation [25].

Organisational characteristics have been highlighted in the literature (e.g., [24]) as possible drivers that may explain the disclosure of specific sustainability information, namely (i) business model, (ii) organisation size, and (iii) industry group. Each of these characteristics is explained below.

Several scholars have underlined the business case for sustainability [26]. These are associated with the creation of value for stakeholders. There are multiple forms of value creation, which are associated with different business models [27]. According to these authors, the most integrative value creation (including economic, social and environmental value) is associated with community platforms (patterns that substitute resource or product ownership with community-based access to them) and some sort of supply chain (patterns that modify upstream and/or downstream components of a business model). Business models may constitute strategic footholds for sustainability implementation 
because they are able to support, on one hand, a more efficient use of resources such as water and energy, and, on the other hand, a decrease of emissions and waste resulted from activities conducted in organisations [28]. These authors identify three groups of business models for sustainability considering the innovation they represent: (i) technological-driven innovations (maximise material and energy efficiency, create value from waste, substitute with renewables and natural processes); (ii) social-driven innovation (deliver functionality rather than ownership, adopt a stewardship role, encourage sufficiency), and (iii) organisational-driven innovation (repurpose for society/environment, develop scale up solutions). The creation of value by these business models is reported to specific stakeholder groups.

The value created may not be necessarily economic, including the creation of knowledge and development of other intangible assets, as suggested by [29]. Intangible assets account for an important part of the organisational value. A high level of intangible assets may support the disclosure of sustainability information in sustainability reports [30].

Disclosure of information may vary based on organisation size (e.g., revenue and number of employees) and perceived corporate performance and impact. Organisation size may influence environmental [21] and social disclosure [22,23]. According to [31], larger organisations disclose more, as well as organisations associated to poor environmental performance. Larger organisations are typically more visible. Therefore, on the one hand, they could be potentially more influenced by legitimacy issues, especially the more the business is dependent on social and political support [19,32]. On the other hand, this tends to put them under the scrutiny of a number of stakeholder groups, which may demand for information [23]. For instance, civilian aviation uses carbon reporting as a way to manage stakeholder relationships in order to reduce potential criticism due to costs variance and emissions' contribution [33].

There has been an increasing awareness of stakeholders for sustainability-related aspects [34]. Organisations are under pressure from stakeholder groups (namely regulators, lenders, insurers, accountants, lawyers, trade and industry customers, consumers and environmentalists) to communicate more and better information about their environmental goals and performance [35] and how environmental, social and economic aspects are embedded into their business strategies and decisions [15]. For instance, sustainability-related information support investment decisions on the organisation [25,36], as it helps investors to make better forecasts on the shares they will receive, and environmental information has been suggested to have a positive effect on financial markets through economic gains and stakeholders' reactions [12].

Considering the disclosure of environmental information, it has been reported that organisations that are more susceptible to criticism (such as oil and gas industries) disclose more information via the media [5]. This demonstrates how organisations can be influenced by the context where they operate. In addition to this, organisations disclose more environmental information online when faced with an environmental crisis, in order to decrease information asymmetry and potential political costs [32], or to reduce potential costs resulted from environmental impacts [24].

A review performed by [37] shows that the most consistent results on the determinants of sustainability disclosure are related to organisational size and visibility (as seen above), but also sector-affiliation. Industry group can help to explain the disclosure of specific information [24]. As suggested by [20], when "established" organisations from a certain industry adopt specific policies, strategies and practices (e.g., environmental and social certifications, business model), there might be an "institutional" pressure to adopt similar structures in order to not jeopardize their chance of survival in the market. This is mainly related to possible isomorphism effects on disclosing sustainability-related information. Institutional isomorphism may support the success and survival of organisations by integrating social norms and expectations [38]. For instance, organisations that belong to economically regulated and resource-intensive sectors report carbon-related information and use this information to increase efficiency and reduce emissions [33].

Despite the above-mentioned arguments, organisation size, industry group, perceived corporate impact [16] and environmental performance [24] may not play a major role in the decision to disclose 
environmental and social information. Organisations with similar characteristics may adopt different policies, strategies and practices in relation to the disclosure of environmental and social information. Mainly two alternative explanations are found in the literature. The variance of the disclosure among organisations could be based on the different policies, strategies and practices adopted by downstream and upstream industries. This is due to the fact that downstream organisations are more under scrutiny of stakeholder groups, such as consumers, when compared to upstream organisations [39]. An example is the consumer goods industry, which typically disclose more information about ethics than other industries [23].

To date, only a limited number of studies have focused on the characteristics of organisations disclosing sustainability-related information. The majority of this research has focused on large organisations and formal reporting schemes, e.g., [40,41]. This indicates a need for further studies on the topic, namely for exploring organisations like SMEs that are generally left out from the academic debate on sustainability disclosure. In addition, the association between the characteristics of the organisations and the content of the information disclosed is unclear.

This study intends to contribute to the still underdeveloped area of research on sustainability measurement and reporting, and organisational theories—as highlighted by [42] — by (i) identifying which environmental and social information do organisations disclose online; and (ii) exploring the organisational drivers affecting the disclosure of sustainability information.

Specifically, our research develops new metrics to assess sustainability information disclosed online by organisations (Section 2.3.1); it provides data on the metrics identified in Section 2.3.1 that is disclosed online by 2008 organisations from twelve industrial groups in Italy (Section 3.1); and explores the association between organisational characteristics (industry group, organisational size, environmental and social certifications, and business model) and the information identified in Section 3.1 (Section 3.2). Organisational characteristics selected are based on the literature presented above.

The paper is structured as follows: Section 2 ("Materials and Methods") presents the method procedures adopted, including the measurement framework, sampling procedure, data collection and analysis; Section 3 ("Results") highlights the main results of this research, providing evidence on what type of environmental and social information organisations disclose, and explores the association between organisational characteristics and the disclosed information; Section 4 ("Discussion") examines the results of this research using a lens of the current literature on the disclosure of environmental and social information; Section 5 ("Conclusions") addresses the main implications of this work and future developments.

\section{Materials and Methods}

This section details the research method developed (Figure 1). It starts by explaining the measurement framework, based on the literature review developed by [18] and international sustainability frameworks and databases on sustainability measurement literature, resulting in the identification of 69 process-based Key-Performance Indicators (KPIs) (Section 2.1). The sampling procedure consisted in a stratified sampling of organisations listed in the AIDA database, comprising all Italian organisations (Section 2.2). Data collection involved environmental and social information available online, including sustainability reports. Online information was considered because it is readily accessible to any stakeholder. This is particularly significant to stakeholder groups who may have online information as the only interface with the organisation. Finally, the procedure for data analysis is based on the development of new metrics to assess information (Section 2.3). 


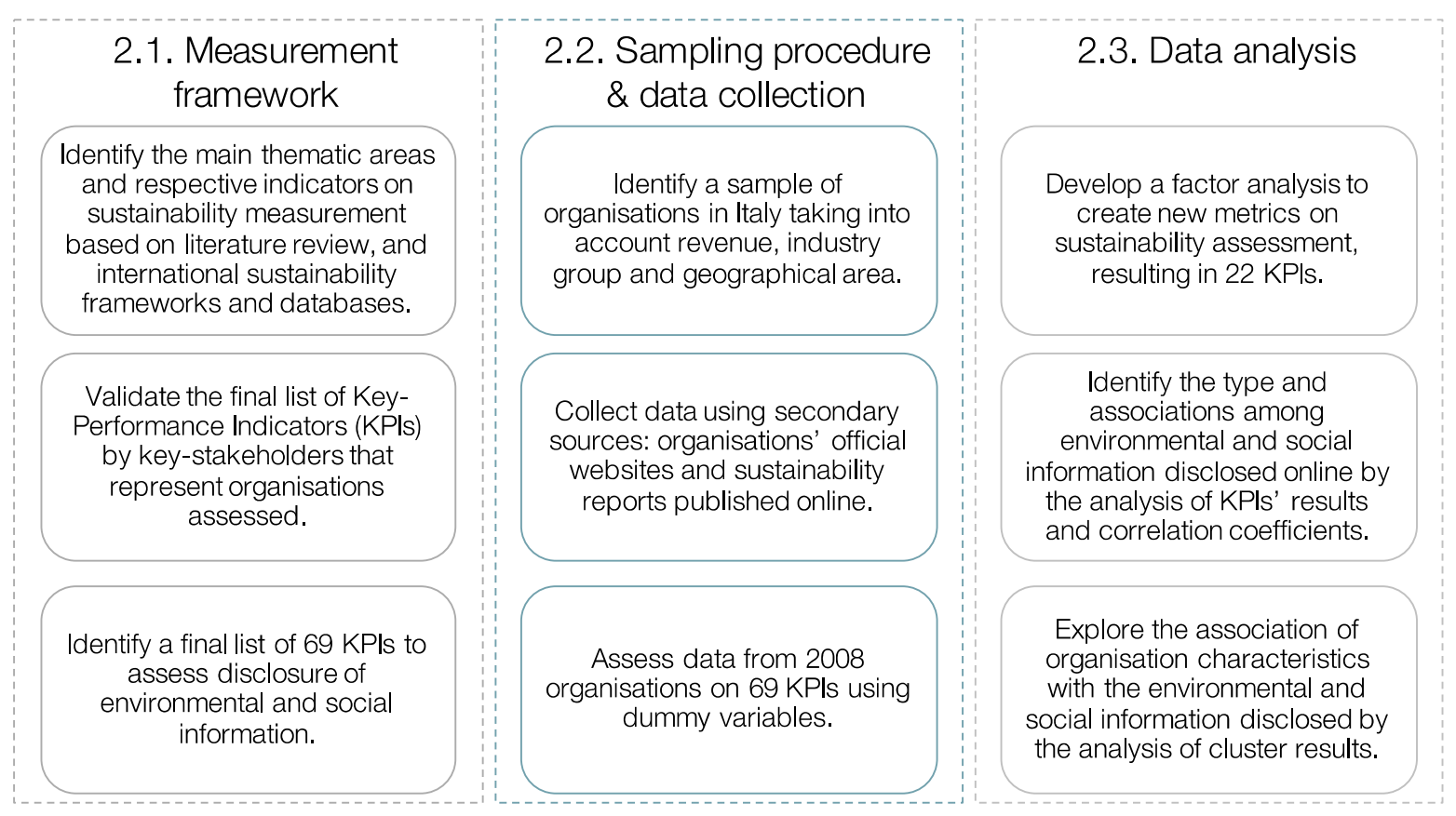

Figure 1. Flowchart of the methods adopted.

\subsection{Measurement Framework}

A measurement framework rooted in international frameworks was designed to collect data. Initially, we identified the main thematic areas on sustainability measurement, and environmental and social indicators based on a comprehensive literature review conducted by [18], as well as international sustainability frameworks and databases (e.g., GRI, Asset4, CDP). A preliminary list of thematic areas and respective indicators was designed and validated by key-stakeholders from twenty Italian SMEs. For this purpose, two focus groups were organised involving 24 key informants overall.

The key-stakeholders were entrepreneurs or members of the senior management team responsible for sustainability-related aspects in their organisation. This allowed to identify a set of 69 KPIs, representing the following thematic areas: environmental certification, social certification, business model, energy, corporate social responsibility, emissions, supply chain, waste management and circular economy, water, product innovation. Appendix A reports the complete list of 69 KPIs. The thematic areas/indices presented in Table A1 are only indicative. Some indicators belong to more than one.

\subsection{Sampling Procedure and Data Collection}

Organisations were selected by stratifying the whole population of Italian organisations by revenues. Revenues represented a reliable proxy for assessing organisational size as it highly correlates (correlation coefficient $>0.90, p$-value $<0.001$ ) with organisation's turnover and number of FTE (correlation coefficients $>0.90, p$-value $<0.001$ ). Data for deriving the stratified sample were retrieved from the AIDA database [43] which comprises specific information (e.g., revenues, turnover, FTE, industrial sector) for all Italian organisations. We choose to employ the stratified sampling procedure after having conducted a pilot study on 400 organisations using random sampling. Random sampling resulted in most organisations being micro firms that do not have a website or actually have a really basic one, therefore severely limiting the data collection procedure.

Following the same theoretical approach, five regions were included, based on their GDP [44,45], organisations' revenues, and considering territorial homogeneity and the number of organisations in these regions. In particular, Emilia-Romagna, Lombardy, Piedmont, Veneto, and Tuscany were selected. Within these five regions, presenting a remarkable manufacturing vocation [46], 2008 organisations representing 12 industrial groups were included into the sample (see Table 1 for details). All industry 
groups considered represent manufacturing organisations. Service organisations were excluded from this analysis. The choice was made based on the major differences presented by service and manufacturing organisations in terms of tangibility of their output, production environment and operation management, even in the perspective of product-service system shifting [47,48]. In addition to this, environmental aspects of manufacturing organisations are subject to a more intensive regulation and, therefore, their approach towards sustainability reporting more mature.

Organisations sampled belong to private sector and more than half of these (1498-70\% of the sample; considering the total revenues) are SMEs. As shown in Table 1, not all industries are represented in all regions and the number of organisations in each industry group differs. Overall, the most represented industries are food (365 organisations), manufacturing of metal products (excluding machinery and equipment-329 organisations) and manufacturing of machinery and other equipment (509 organisations). These three industries alone represent $60 \%$ of the organisations in the sample. The number of organisations in each region is also unequal: 760 organisations are located in Lombardy, 400 in Piedmont, 369 in Emilia-Romagna, 299 in Veneto, and 180 in Tuscany. We will not present results considering differences between regions as the results from the Kruskal-Wallis $\mathrm{H}$ test performed were not significant between regions (for details about this test see Section 2.3.2).

Table 1. List of industry groups and respective characteristics.

\begin{tabular}{|c|c|c|}
\hline Industry Group & $\begin{array}{l}\text { Total Number } \\
\text { (Percentage) }\end{array}$ & $\begin{array}{c}\text { Geographical Distribution } \\
\text { (Percentage) }\end{array}$ \\
\hline \#1. Food industry & $365(18 \%)$ & $\begin{array}{c}\text { Emilia-Romagna }(33 \%) \\
\text { Lombardy }(34 \%) \\
\text { Piedmont }(14 \%) \\
\text { Veneto }(19 \%)\end{array}$ \\
\hline \#2. Textile industry & $25(1 \%)$ & Tuscany $(100 \%)$ \\
\hline \#3. Manufacturing of leather and similar products & $85(4 \%)$ & $\begin{array}{l}\text { Tuscany }(47 \%) \\
\text { Veneto }(53 \%)\end{array}$ \\
\hline $\begin{array}{l}\text { \#4. Manufacturing of paper and products derived } \\
\text { from paper }\end{array}$ & $20(1 \%)$ & Tuscany $(100 \%)$ \\
\hline \#5. Manufacturing of chemical products & $155(8 \%)$ & Lombardy (100\%) \\
\hline \#6. Manufacturing of rubber and plastic materials & $40(2 \%)$ & Piedmont $(100 \%)$ \\
\hline $\begin{array}{l}\text { \#7. Manufacturing of other products to produce } \\
\text { non-metallic minerals }\end{array}$ & $40(2 \%)$ & Emilia-Romagna (100\%) \\
\hline \#8. Metallurgy & $180(9 \%)$ & $\begin{array}{l}\text { Lombardy }(81 \%) \\
\text { Tuscany }(19 \%)\end{array}$ \\
\hline $\begin{array}{l}\text { \#9. Manufacturing of metal products (excluding } \\
\text { machinery and equipment) }\end{array}$ & $329(16 \%)$ & $\begin{array}{c}\text { Emilia-Romagna }(15 \%) \\
\text { Lombardy }(47 \%) \\
\text { Piedmont }(15 \%) \\
\text { Veneto }(23 \%)\end{array}$ \\
\hline $\begin{array}{l}\text { \#10. Manufacturing of electrical equipment and } \\
\text { equipment for domestic non-electrical use }\end{array}$ & $30(1 \%)$ & Veneto $(100 \%)$ \\
\hline \#11. Manufacturing of machinery and other equipment & $509(25 \%)$ & $\begin{array}{c}\text { Emilia-Romagna }(24 \%) \\
\text { Lombardy }(35 \%) \\
\text { Piedmont }(14 \%) \\
\text { Tuscany }(12 \%) \\
\text { Veneto }(16 \%)\end{array}$ \\
\hline \#12. Manufacturing of vehicles, trailers and semi-trailers & $230(11 \%)$ & $\begin{array}{l}\text { Emilia-Romagna (17\%) } \\
\text { Piedmont }(83 \%)\end{array}$ \\
\hline
\end{tabular}


Between April and June 2017, data was collected on the 2008 organisations using the 69 KPIs through secondary sources-i.e., organisation's websites and sustainability reports published online. Each indicator was evaluated using dummy variables, which measured whether or not an organisation discloses that sustainability-related practice/indicator on its official websites and documents available online.

The collection of data was supported by 40 students. Three workshops were organised for aligning them on the measurement framework and on the data collection process. Students were assigned 50 organisations each to increase reliability in data results. After the first round of data collection, random checks were performed by the authors to validate the dataset. Random checks were performed by the authors of this paper in approximately $5 \%$ of the collected data and resulted in marginal revisions (below 1\%) of the data retrieved by the students.

\subsection{Data Analysis}

\subsubsection{Development of New Metrics to Assess Sustainability Aspects Disclosed Online}

In order to reduce the dimensionality of the measurement framework proposed and to investigate the presence of underlying latent factors that could describe and synthesize the data collected, we conducted an exploratory factor analysis.

A seven-factor model resulted from our analyses, and the factors were reflected by 22 KPIs that remained after the analyses. Both convergent and discriminant validity were supported, and the reliability coefficients of Cronbach's $\alpha$ and Guttman's $\lambda 2$ were above the expected threshold of 0.60 .

Table 2 depicts the final list of 22 KPIs from the factor analysis considered and respective factors. It can be noticed that some thematic areas were not considered, such as energy, as the factor loadings were under 0.40 and the reliability coefficients of the overall factor were below the expected threshold of 0.6. This shows energy related information is not strong enough to emerge as an independent factor.

The final values for each thematic area were calculated based on the results of the factor analysis. The final value of each thematic area is represented by the sum of the factor loadings multiplied by the respective measured values. These were used to analyse data in aggregated form (Section 3.1 and part of Section 3.2).

\subsubsection{Correlation Coefficients and Differences between Industry Groups}

Data were then analysed through descriptive and inferential statistics. Firstly, a Shapiro-Wilk test was performed in order to test if data are normally distributed. The null hypothesis was rejected as $p>0.05$ for all variables. Thus, non-parametric tests were performed in subsequent analyses.

Cross-tabulations were used to examine possible associations between indices and organisational characteristics. Characteristics analysed include (i) size of the organisation, considering revenue, and number of employees; (ii) industry group, (iii) environmental and (iv) social certifications, and (v) business model. Environmental and social certifications, and business model were evaluated through three indices (Section 2.3.2.1).

When patterns were detected between variables, correlation coefficients were calculated. A Kruskal-Wallis $\mathrm{H}$ test was performed in order to determine if there were statistical differences between the disclosure of environmental and social information between at least two industry groups. 
Table 2. Indicators used in the analysis and respective results from the factor analysis.

\begin{tabular}{|c|c|c|c|c|c|c|c|c|c|}
\hline \multirow[b]{2}{*}{$\begin{array}{l}\text { Thematic } \\
\text { Areas/Indices }\end{array}$} & \multirow{2}{*}{\multicolumn{2}{|c|}{ Indicator }} & \multicolumn{7}{|c|}{ Factor Loadings } \\
\hline & & & CSR & EM & SP & WM & $\mathrm{CE}$ & WA & PD \\
\hline \multirow{4}{*}{$\begin{array}{l}\text { Corporate Social } \\
\text { Responsibility } \\
\text { (CSR) }\end{array}$} & CSR1 & Statement or policy of equal opportunities & 0.91 & & & & & & \\
\hline & CSR2 & Ethical code & 0.95 & & & & & & \\
\hline & CSR3 & $\begin{array}{l}\text { Development of training policies / training for employees } \\
\text { (beyond mandatory regulation) }\end{array}$ & 0.50 & & & & & & \\
\hline & CSR4 & $\begin{array}{l}\text { Risk analysis policy for employees' protection in the } \\
\text { working environment }\end{array}$ & 0.70 & & & & & & \\
\hline \multirow{5}{*}{ Emissions (EM) } & & Monitor of environmental impacts caused by: & & & & & & & \\
\hline & EI1 & Air emissions & & 0.45 & & & & & \\
\hline & EI2 & Land emissions and spills & & 0.97 & & & & & \\
\hline & EI3 & Water emissions & & 0.95 & & & & & \\
\hline & EI4 & Identification of specific objectives to reduce emissions & & 0.29 & & & & & \\
\hline \multirow{4}{*}{ Supply chain (SP) } & SP1 & Environmental and social criteria to select suppliers & & & 0.54 & & & & \\
\hline & SP2 & Policy to reduce environmental impacts of the supply chain & & & 0.77 & & & & \\
\hline & SP3 & $\begin{array}{l}\text { Description of the origin of the resources used and the origin } \\
\text { of production (product transparency and "Made in Italy") }\end{array}$ & & & 0.64 & & & & \\
\hline & SP4 & $\begin{array}{l}\text { Communication policies to inform consumers about the } \\
\text { sustainability of the products }\end{array}$ & & & 0.70 & & & & \\
\hline \multirow{2}{*}{$\begin{array}{l}\text { Waste Management } \\
\text { (WM) }\end{array}$} & WM1 & Separated waste collection & & & & 0.92 & & & \\
\hline & WM2 & Separated waste collection description & & & & 0.68 & & & \\
\hline \multirow{2}{*}{$\begin{array}{l}\text { Circular economy } \\
\text { (CE) }\end{array}$} & CE1 & $\begin{array}{c}\text { Use of recycled materials in the manufacturing of the } \\
\text { products }\end{array}$ & & & & & 0.89 & & \\
\hline & CE2 & Flawed product recycling & & & & & 0.60 & & \\
\hline \multirow{3}{*}{ Water (WA) } & WA1 & Treatment/purification/capture plant of wastewater & & & & & & 0.56 & \\
\hline & WA2 & Treatment/purification/capture plant of rainwater & & & & & & 0.39 & \\
\hline & WA3 & Amount of re-used water & & & & & & 0.84 & \\
\hline \multirow{4}{*}{$\begin{array}{l}\text { Product innovation } \\
\qquad(\mathrm{PD})\end{array}$} & PD1 & $\begin{array}{l}\text { Description of initiatives in place to reduce the energy } \\
\text { footprint of products during the use phase }\end{array}$ & & & & & & & 0.61 \\
\hline & & vironmental product innovation policy/initiative on: & & & & & & & \\
\hline & PD2 & Eco-design & & & & & & & 0.61 \\
\hline & PD3 & Life-cycle assessment & & & & & & & 0.39 \\
\hline
\end{tabular}




\subsubsection{Contingent Variables}

Table 3 presents the list of indicators used to create three indices corresponding to environmental certifications, social certifications, and business models. Following the nomenclature presented by [27], indicators associated to business models are mainly based on environmental forms of value creation (positive in the case of BM1, BM2 and BM3; and negative in the case of BM4). The four items have been taken from the standard Asset4, and they have been designed to capture the type of product (e.g., a specific technology) manufactured by the organisation and the industry group in which the organisation operates. These represent business models based on technological-driven innovations [28]. Indicators related to environmental and social certifications were also considered, as these are many times used by organisations to signal a commitment to sustainability.

Indices are calculated using the standardised sum of the respective indicators. These indicators were separated from the indices presented in Table 2, which represent processes or organisation behaviour characteristics. Indices in Table 3 are used as contingent variables as they can affect the other variables being assessed. They are a real binary variable (an organisation can have a certification or not) whilst the other indices presented in Table 2 can potentially be measured continuously. These data were collected in a similar way as described in Section 2.1, through the use of dummy variables.

Table 3. Indices used as contingent variables.

\begin{tabular}{ccc}
\hline Thematic Areas/Indices & & Indicator \\
& & Existence of: \\
& EC1 & ISO 14001 \\
Environmental & EC2 & EMAS \\
certification (EC) & EC3 & ISO 50001 \\
& EC4 & Ecolabels (e.g., FSC, Energy star, MSC, EU ecolabel) \\
& EC5 & GOLDPOWER \\
& EC6 & LEED \\
& & Existence of: \\
& SC1 & SA 8000 \\
& SC2 & ISO 26000 \\
& SC3 & OHSAS 18001 \\
& SC4 & IFS \\
& SC5 & ISO 22005 \\
& SC6 & ISO 22000 \\
& & BM1
\end{tabular}

\subsubsection{Cluster Analysis}

A hierarchical cluster analysis was conducted in order to draft the simplest structure that represents homogeneous grouping of organisations [49]. Firstly, a hierarchical clustering algorithm was used to support the selection of the number of clusters as representative of the structure of the data [49]. The average linkage algorithm (using a Euclidean distance measure) was used as it does not depend on extreme values, it tends to generate clusters with small variation within the cluster [49].

The cluster solution was achieved by (i) analysing the dendrogram resulted from the hierarchical cluster, (ii) the results from the Calinski-Harabasz pseudo-F stopping rule-index (the largest values the more distinct clustering), and Duda-Hart Je(2)/Je(1) stopping rule-index (the largest values the more distinct clustering); and (iii) the results from pseudo-T-squared values (the smallest values the more 
distinct clustering). After this, based on the number of clusters chosen, a non-hierarchical clustering analysis was conducted using the K-means algorithm.

A Kruskal-Wallis $\mathrm{H}$ test was performed to evaluate the significance of clustering variable differences. The results of the cluster analysis are not generalisable as they depend on the structure of the existent data [49]. Nevertheless, they allow us to identify the status quo and possible trends of the Italian organisations assessed.

A radar chart was used to represent the clusters. For this purpose, an internal normalisation method was used. We attributed value 1 to the best performance on a thematic area $i$ and we calculated the proportional value to the other performances dividing each performance by 1 . All thematic areas are to maximise, i.e., the higher value the better. As stated before, these results depend on the alternatives being analysed.

\section{Results}

\subsection{Type of Environmental and Social Information Disclosed by Organisations Online}

Environmental and social information disclosed by organisations online is low. CSR indicators are among the type of information most disclosed on organisations' websites (2887 times CSR indicators were found online), whilst indicators related to water are the least disclosed (376 times Water indicators were found online).

Figure 2 shows the top 10 indicators most disclosed online among the organisations assessed. It can be seen that all indicators considered under the CSR index are included in this list; and the most disclosed is one of the contingent variables, i.e., EC1 Environmental certification according to ISO 14001. In particular, the adoption of ISO 14001 (EC1) is disclosed by $50 \%$ of the organisations in the manufacturing of paper and products derived from paper (\#4), manufacturing of rubber and plastic materials (\#6), and manufacturing of electrical equipment and equipment for domestic non-electrical use (\#10).

Figure 3 illustrates the 10 indicators least disclosed online, which include environmental and social certification-related and water indicators. These charts include indicators resulted from the factor analysis (Table 2, Section 2.3.1) and indicators used as contingent variables (Table 3, Section 2.3.2).

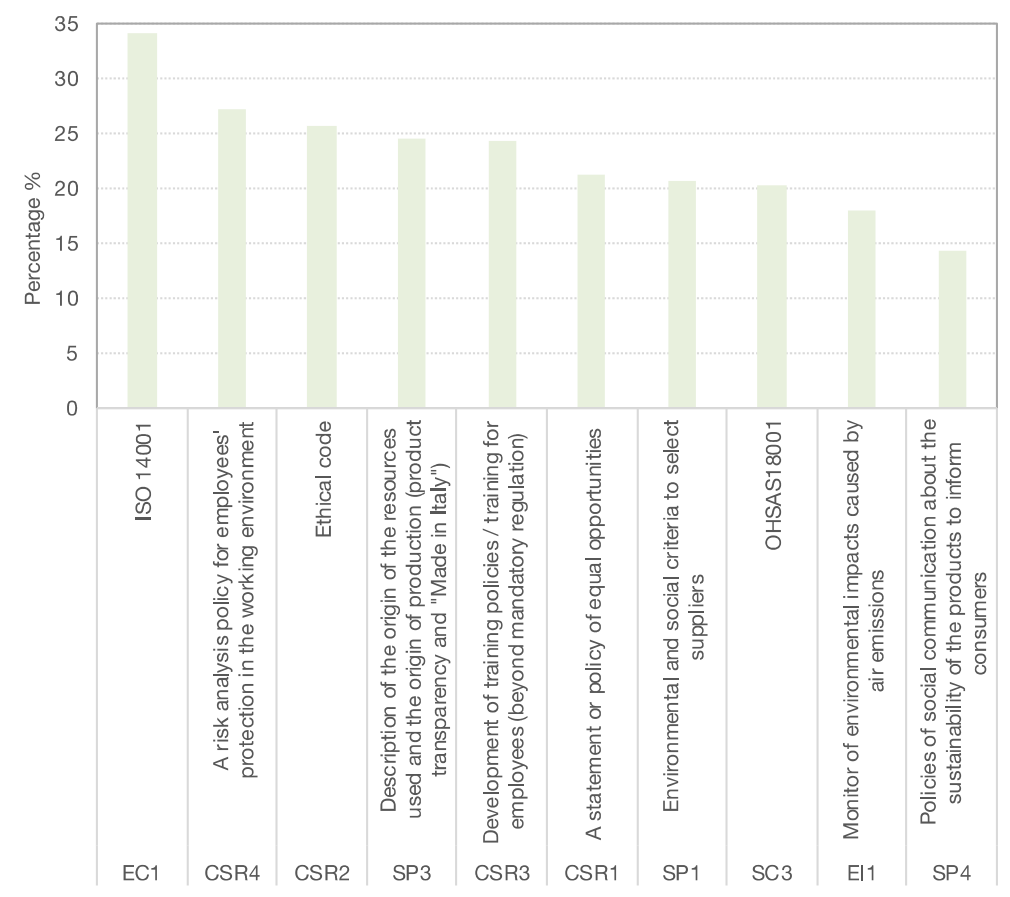

Figure 2. Top 10 indicators most disclosed online among the organisations assessed. 


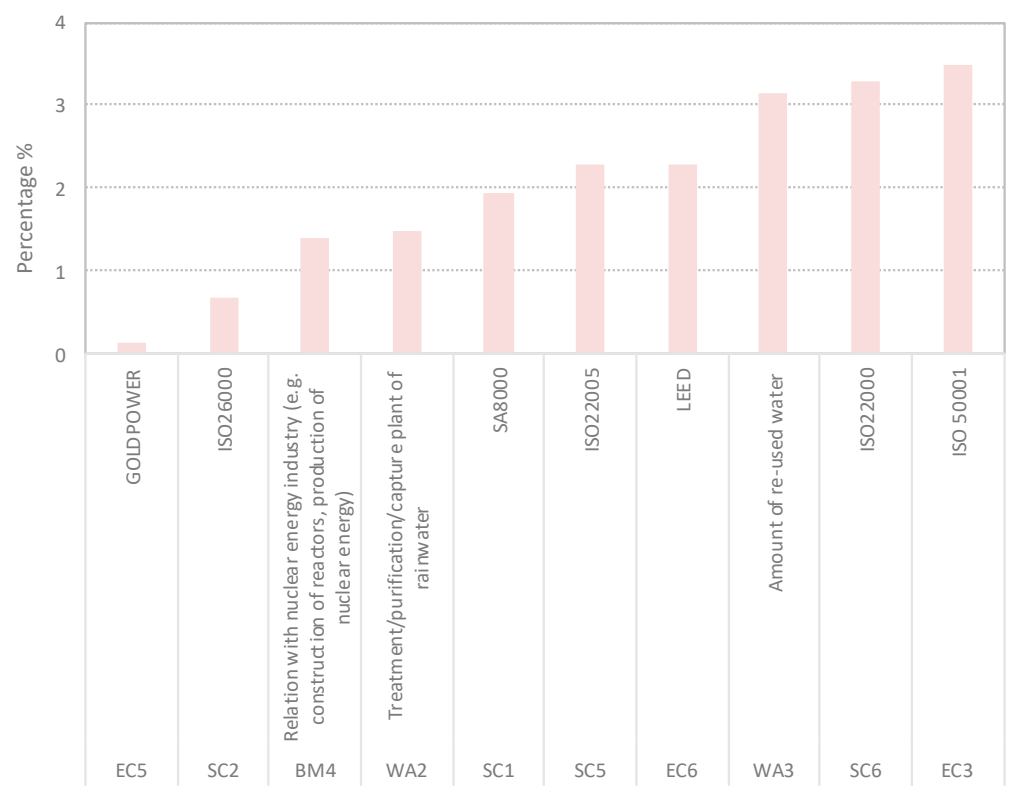

Figure 3. Top 10 indicators least disclosed online among the organisations assessed.

3.2. Association between Organisation Characteristics (Industry Group, Organisational Size, Environmental and Social Certifications and Business Model) and Environmental and Social Information Disclosed Online

\subsubsection{Correlation Coefficients and Differences between Industry Groups}

Table A2 in Appendix B depicts the Spearman's rank correlations between organisational characteristics, contingent variables and indices. Figure 4 illustrates the cases with a significant correlation (rho $>0.4$ ) for $p<0.01$.

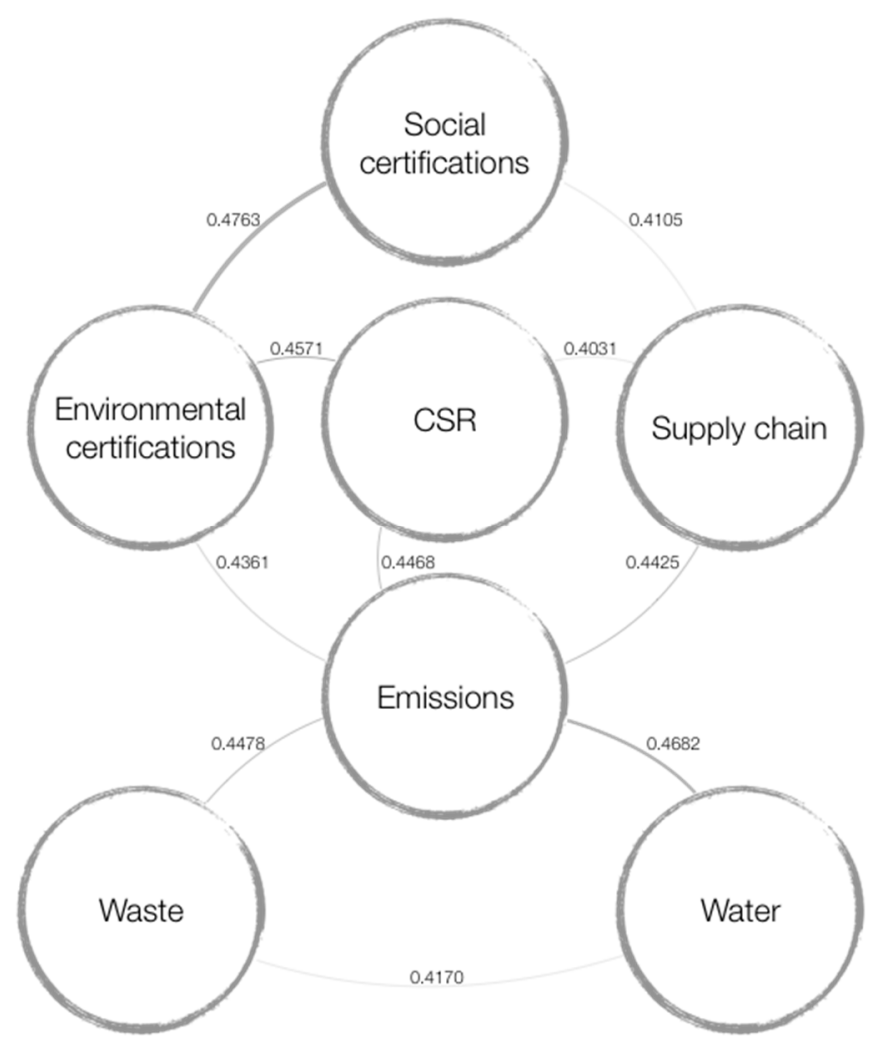

Figure 4. Thematic areas/Indices most significantly correlated considering a coefficient rho $>0.4$. 
Through the application of a Kruskal-Wallis $\mathrm{H}$ test, it was found that the differences between environmental and social information disclosed and industry groups are statistically significant. The results of the test are shown in Table 4 associated to a $p<0.001$. There is evidence showing that disclosure of some environmental and social information is significantly statistically different between industry groups. A cluster analysis was performed in order to study in more detail which type of information and industry groups are responsible for this difference.

Table 4. Results of the Kruskal-Wallis equality-of-populations rank test for the industry groups.

\begin{tabular}{cc}
\hline Thematic Area & $\boldsymbol{\chi} \mathbf{2 ~ ( 1 1 )}$ \\
\hline CSR & 46.446 \\
EM & 85.411 \\
SP & 369.846 \\
WM & 79.213 \\
WA & 204.853 \\
CE & 203.568 \\
PD & 112.209 \\
\hline
\end{tabular}

\subsubsection{Cluster Analysis}

A cluster analysis was conducted following the method described in Section 2.3.3. A solution of five clusters was achieved (Table 5). Results from the cluster analysis are illustrated in Figure 5 (normalised values). All mean scores presented are significant for $p<0.01$.

Table 5. Mean scores from the cluster results achieved (normalised values used for Figure 5 presented in brackets).

\begin{tabular}{ccccccccc}
\hline Cluster & CSR & EM & SP & WM & CE & WA & PD & $\begin{array}{c}\text { Number of } \\
\text { Organisations }\end{array}$ \\
\hline \multirow{2}{*}{ A } & 2.143 & 2.328 & 1.617 & 0.684 & 0.511 & 0.563 & 0.423 & 144 \\
& $(0.76)$ & $(1.00)$ & $(1.00)$ & $(1.00)$ & $(1.00)$ & $(1.00)$ & $(1.00)$ & \\
B & 1.698 & 0.143 & 0.188 & 0.054 & 0.087 & 0.026 & 0.055 & 231 \\
& $(0.60)$ & $(0.06)$ & $(0.12)$ & $(0.08)$ & $(0.17)$ & $(0.05)$ & $(0.13)$ & \\
C & 2.831 & 0.239 & 1.049 & 0.207 & 0.164 & 0.107 & 0.170 & 241 \\
& $(1.00)$ & $(0.10)$ & $(0.65)$ & $(0.30)$ & $(0.32)$ & $(0.19)$ & $(0.40)$ & \\
D & 0.186 & 0.133 & 1.081 & 0.108 & 0.132 & 0.093 & 0.106 & 383 \\
& $(0.07)$ & $(0.06)$ & $(0.67)$ & $(0.16)$ & $(0.26)$ & $(0.17)$ & $(0.25)$ & \\
E & 0.043 & 0.032 & 0.007 & 0.017 & 0.030 & 0.007 & 0.023 & 1009 \\
& $(0.02)$ & $(0.01)$ & $(0.00)$ & $(0.02)$ & $(0.06)$ & $(0.01)$ & $(0.05)$ & \\
\hline
\end{tabular}

Cluster A (144 organisations) encompasses organisations with the highest disclosure of information; at the same time, the fewer number of organisations are represented here. Cluster B (231 organisations) represents organisations with low disclosure in most indices, except CSR. Cluster C (241 organisations) represents the highest disclosure of information related to CSR. Cluster D (383 organisations) contains organisations that in general present a low disclosure of information, but high disclosure of supply chain-related information. Cluster E (1009 organisations) represents organisations that disclose the least information online in every thematic area; it represents the majority of the sample analysed.

The number of organisations is different among industry groups, so the results are interpreted considering the representativeness of the organisations of a specific group in each cluster (Figure 6). Most industry groups are represented in every cluster, except the textile industry, which is not represented in Cluster B. It is not possible to state that organisations from specific industry groups have a specific behaviour regarding disclosure of environmental and social information online. However, some trends are recognisable from results obtained and they are described in the following. 


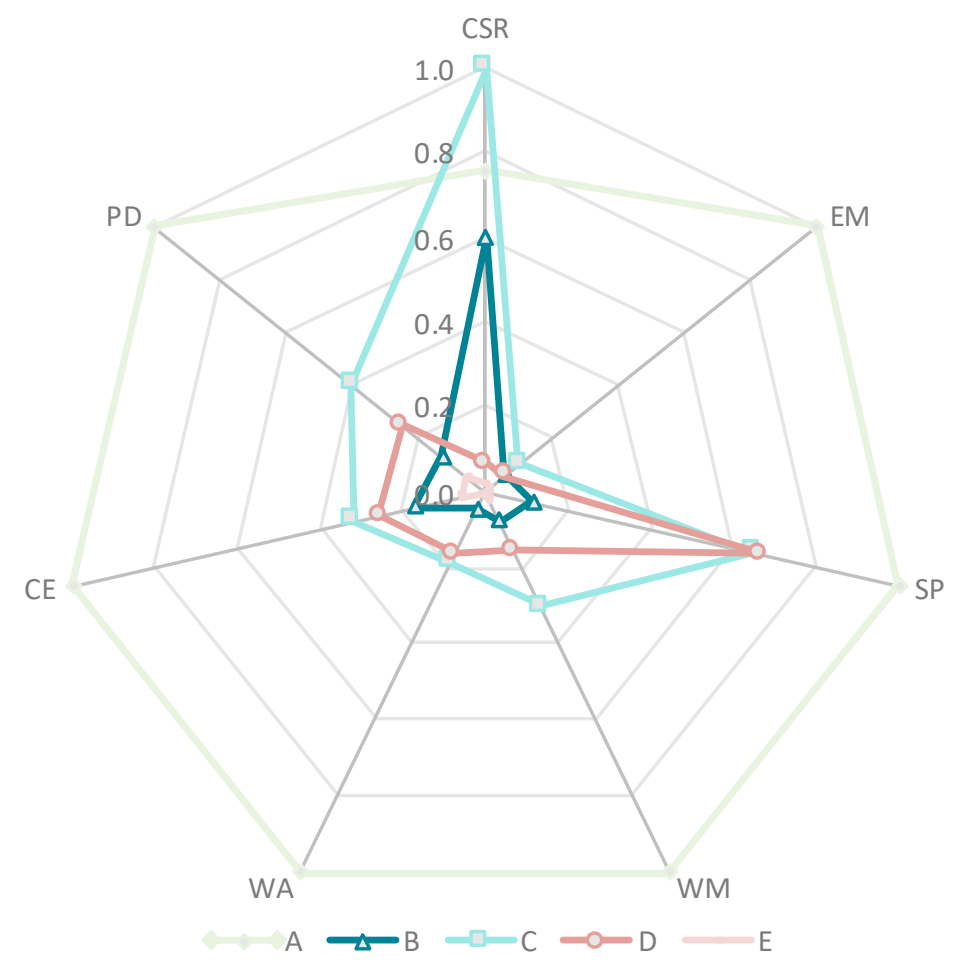

Figure 5. Cluster results achieved (mean scores normalised).

Most organisations of each industry group are represented in Cluster E, which characterises organisations with the least environmental and social information disclosed online. It is associated to an average lower number of employees, compared to the other clusters. In this cluster, $81 \%$ of the organisations do not disclose information about any environmental certificate and $89 \%$ do not disclose any information about any social certificate. In the same line, $93 \%$ of the organisations in this cluster do not disclose information about any of the business models.

Cluster A includes organisations that most disclose in the majority of the thematic areas, with the exception of CSR. Even though all industry groups are represented in this cluster, industry groups related to consumer goods are the most significant presence: $28 \%$ of organisations in textile industry (\#2), $20 \%$ of organisations in manufacturing of paper and products derived from paper (\#4), and $20 \%$ of organisations in manufacturing of other products to produce non-metallic minerals (\#7) (mainly organisations related to glass and ceramic manufacturing). Industries related to consumer goods develop products readily available to the final consumer. Thus, they can be considered downstream industries.

This cluster is also associated to an average revenue (176 hundred million euros) and number of employees (770) higher than the average in other clusters (which is lower than 53 million euros in revenues and less than 420 employees). Most organisations in Cluster A are not SMEs. In addition to this, $46 \%$ of these organisations reports of at least two environmental certifications; and $44 \%$ of at least one social certifications. Only $36 \%$ disclose information of at least one business model. It is important to note the low number of times any of the business models are mentioned on the official websites.

Cluster B and C are characterised by an overall low disclosure in all thematic areas, except in CSR. Cluster $\mathrm{C}$ represents organisations that disclose more information on CSR among all clusters. Some of the organisations represented in these clusters are related to resource intensive sectors. There are $23 \%$ of organisations that belong to manufacturing of chemical products (\#5) (namely oil companies) and $20 \%$ of organisations related to manufacturing of electrical equipment and equipment for domestic non-electrical use (\#10) belong to Cluster B; and $25 \%$ of the organisations in manufacturing of rubber and plastic materials (\#6) belong to Cluster C. 
Cluster D represents organisations with an overall low disclosure of environmental and social information, but high disclosure of information related to supply chain. Organisations from three industry groups related to consumer goods are considerably represented in this cluster: $48 \%$ of the organisations in the food industry (\#1), 35\% of the organisations in manufacturing of paper and products derived from paper (\#4), and $43 \%$ of the organisations in manufacturing of other products to produce non-metallic minerals (\#7).

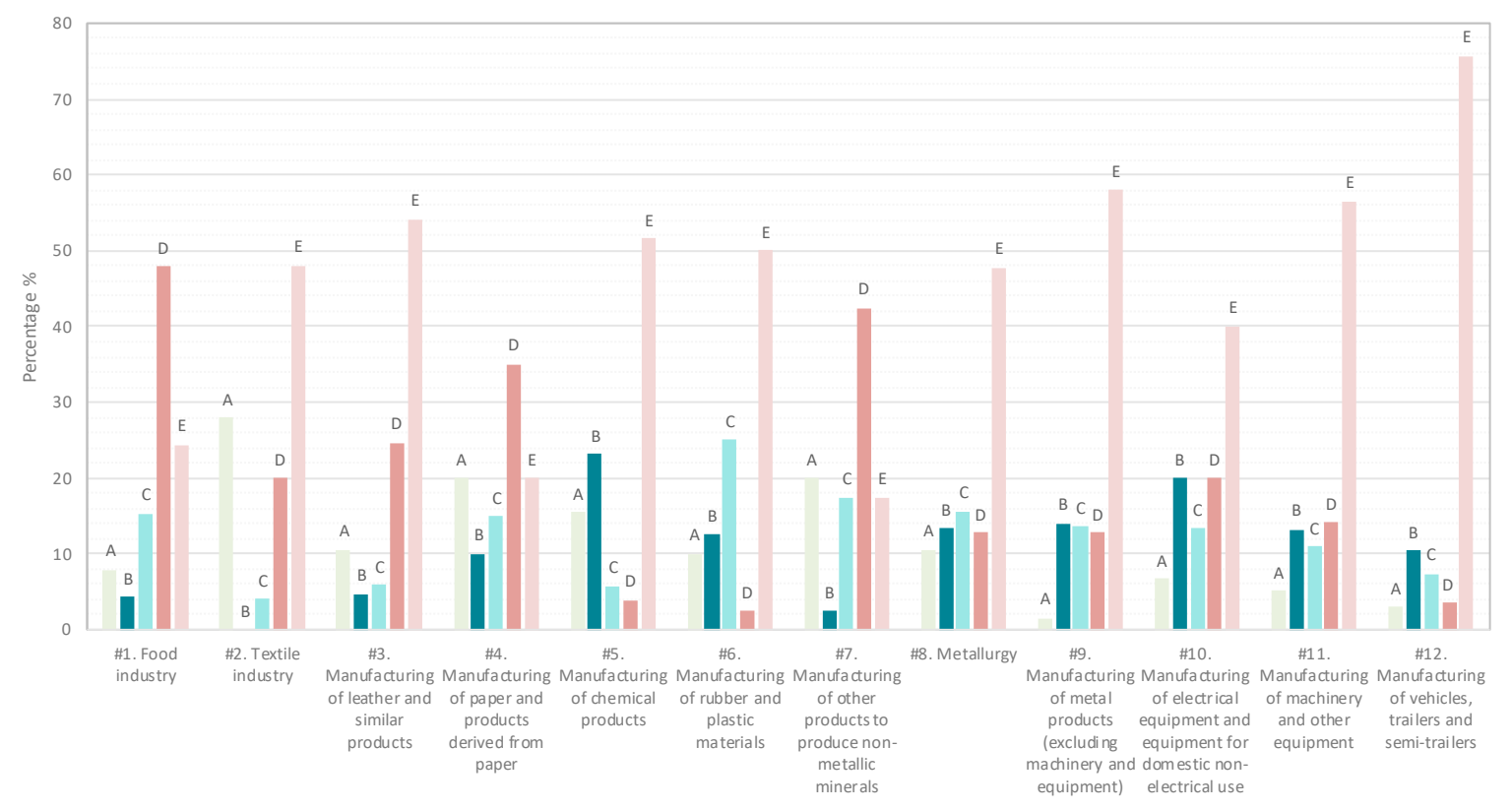

Figure 6. Distribution of organisations by industry group in each cluster.

\section{Discussion}

Our first result is mainly methodological and concerns the development of new metrics to assess sustainability-related information disclosed online by organisations (Section 2.3.1). The results of the factor analysis identified seven indices belonging to different thematic areas (factors): Corporate Social Responsibility, Emissions, Supply Chain, Waste Management, Circular Economy, Water, Product Innovation. Some of the thematic areas initially identified during the literature review were not retained as independent factors after the factor analysis was conducted. For instance, KPIs related to energy. Previous research has found that in most cases reporting information related to energy and materials is independent from reporting information about emissions and water [25]. According to these authors, this depends on the governance system of the organisation. Organisations that operate in civil law countries (most European countries, including Italy) report mostly on emissions and water issues; whilst organisations operating in common law countries report mainly information on energy and materials (countries based on the English common law). This appears consistent with our results. Information disclosed online about emissions and water emerged as independent factors among the information disclosed by the Italian organisations assessed.

Considering the overall amount of sustainability-related information available on organisations' official websites, our findings suggest that environmental and social information disclosed are still low. As a matter of fact, $50 \%$ of the organisations in our sample belong to Cluster E, that shows the normalised value of all sustainability indices to be close to zero. This finding is in line with previous results in the field of online sustainability disclosure [22].

Considering the content of the information disclosed, CSR and environmental certifications are among the most disclosed information. According to [50], CSR is used by SMEs to minimize problems that these organisations usually face, such as financial constraints and difficulties in attracting high qualified employees. CSR also supports SMEs to improve their competitiveness. This type of 
information seems to be typically disclosed by organisations to gain, maintain or repair legitimacy to operate [11,12], signal a commitment with external parties [18], and reinforce a desired organisational identity [51]. According to previous studies, awareness of stakeholders for sustainability-related aspects has been increasing [34]. In addition to this, CSR-related information is significantly correlated to environmental certifications, emissions and supply chain which indicate that organisations may disclose this type of information together (Section 3.2.1).

Environmental certifications may enhance the disclosure of environmental information by organisations, as suggested by [21]. Organisations become more aware of their processes of activities thanks to the procedures required to gain environmental certifications. Thus, organisations with environmental certifications may disclose more sustainability-related information. This may suggest that the organisational culture, and business strategy consequently implemented, may play an important role in the decision to disclose environmental and social information related to the activities adopted.

Turning to explore the association between organisational characteristics and the information identified, our results show a significant difference among industry groups in the content of the information disclosed. Cluster analysis highlighted that consumer goods and resource-intensive sectors show the highest degree of disclosure.

In particular, consumer goods-related industries focused on the disclosure of supply chain-related information. This is represented in Cluster $\mathrm{D}$, which has a higher disclosure of supply chain-related information when compared to the other clusters, and it is mostly constituted by consumer goods organisations that are closer to the final consumers and under the scrutiny of different stakeholder groups [39]. Our results also confirm findings from [23] as consumer goods organisations disclose more information about CSR and ethics than other organisations in our sample. Therefore, consumer goods organisations show isomorphism effects in disclosing specific sustainability-related information as suggested by [24].

Additionally, resource-intensive sectors can also be considered under scrutiny of different types of stakeholder groups such as environmental non-governmental organisations and the public opinion. Our results showed that organisations related to resource-intensive sectors disclose mostly information about CSR. Literature reports that these organisations are under scrutiny of various stakeholder groups since they are more dependent on social and political support $[19,32]$ and may be more vulnerable to criticism [5]. This happens because resource-intensive organisations are frequently dependent by both governmental subsides and acceptance of their activities by key-stakeholder groups identified above. According to [52], corporate managers believe that people care about the way organisations affect the environment, recognizing their environmental performance. Research has previously shown that disclosure of environmental information by these groups is mainly to reduce potential criticism $[5,33]$. Consequently, the disclosure of information related to CSR is mostly used. In fact, results of the cluster analysis illustrate that a significant percentage of organisations belonging to industries associated to resource-intensive sectors (manufacturing of chemical products, namely oil organisations; electrical equipment and equipment for domestic non-electric use; and rubber and plastic materials) belong to the clusters related to a low disclosure in all thematic areas except CSR. This type of information is typically oriented to the general public, instead of towards specific stakeholder groups. This results in a lack of concrete information about how significant negative impacts of the activities of these organisations affect for instance ecosystems. This is mainly due to the fact that this information needs to be generic in order to be understood by non-experts. Consequently, CSR is frequently used to reinforce a desired organisational identity [51].

Despite the overall low disclosure, our results also identified a small group of organisations $(7 \%$ of the organisations in our sample) belonging to Cluster A, that displays high values of disclosure in all the sustainability indices and also in business model characteristics. Disclosure on business models is important in order to understand how value is created and in which form (e.g., integrative, economic, social, environmental) as detailed by [27]. As explained in the first section of this paper, the disclosure of sustainability information and organisation's value creation for stakeholders are 
suggested to be deeply intertwined. This value includes the development of intangible assets that are highly relevant for capital markets [53]. Thus, the importance of measuring and disclosing information not only related to purely financial aspects is considered to be very important for organisations.

Our results also suggest that larger organisations disclose more sustainability-related information than SMEs, thus supporting [21-23,31]. These findings are consistent with extant literature in the field regarding size-dependency of information disclosure. Larger organisations, in fact, tend to disclose more information, compared to smaller ones. Thus, as most organisations in our sample are SMEs, the low number of environmental and social information disclosed online is expected. This may be related to less resources available for formal reporting activities and to a different reaction that SMEs have to stakeholders' pressures compared to large organisations.

According to [54], since smaller organisations are more embedded in the social environment they contribute to, they usually respond more directly to stakeholder pressures, namely from internal groups, local communities, commercial buyers, household consumers, supply chain stakeholders and regulatory agencies. This may be due to their simplified decision-making process, greater innovation propensity, and resource scarcity (e.g., less resources to litigate the claims) [54]. This suggest stakeholder pressures may not have played a major role in disclosure of environmental and social information in the organisations assessed as overall the information disclosed is low. One of the reasons may be the fact that the activities of these organisations are not as visible as larger organisations. SMEs have an advantage in developing collaborative business cases for sustainability because there are less "layers of managements" involved in the decision making [55]. This could include the disclosure of information in different ways, where key stakeholders can be engaged in different phases of the process, namely through online reporting [7], for instance, using social media [56]; or as a complement to formal reporting schemes selecting report's content and design [9], but also collecting data, analysing and monitoring results [57].

\section{Conclusions}

This research develops new metrics to assess sustainability aspects related to environmental and social aspects, such as CSR, emissions, supply chain, waste, water, circular economy, and product innovation. It provides data on the type of environmental and social information disclosed online by 2008 organisations from twelve industrial groups in Italy; and explores the association between organisational characteristics and the information disclosed online.

This paper explores the possible relevance given by organisations to the communication of certain type of information online. This constitutes public information that any stakeholder can access to be informed about policies, strategies and practices related to corporate sustainability. In addition to this, it also suggests the type of organisational culture and business strategies adopted; and information that some stakeholder groups (internal and external) may be requiring. Overall, information disclosed to stakeholders is low, which shows that even a one-way communication channel (from the organisation to stakeholders) is still weak. This is particularly significant to stakeholder groups who may have online information as the only interface with the organisation. Yet, there is a significant disclosure of information related to CSR and environmental certifications.

We provide further evidence that larger organisations tend to disclose more environmental and social information, especially when already engaged in certification procedures. We also found that organisations related to consumer goods disclose mostly information related to supply chain; and resource-intensive industries disclose mostly information on CSR. These organisations may be disclosing this type of information as an effort to legitimise their activities in a one-way communication channel. However, there is a lack of evidence on the feasibility of this information, especially when organisations related to resource-intensive activities disclose sustainability-related information.

This study provides researchers and practitioners with information on the content of sustainability information disclosed and possible drivers for their disclosure; this supports their understanding on the conditions where voluntary sustainability disclosure is more expected. The findings of this paper 
can help to understand the reasons behind disclosing a specific type of information and distinguish between valuable information from possible window dressing. In addition, we believe data and results presented must be regarded as an opportunity for business and policy makers to understand content and drivers of online sustainability disclosure. In particular, to acknowledge the impact of the current policies in the Italian context, and plan future developments.

Some limitations of this study are worth noting. The research design may influence the results as it is based on what organisations choose to communicate, which does not allow to evaluate the quality or the extent to which the indicators/practices are embedded in the organisational strategies and operational activities. In addition, online information may vary faster than formal reporting as it is easily reachable and then visible. Consequently, changes on the characteristics of the organisational culture and organisational stakeholder groups may influence the type and amount of environmental and social information. Further studies could also apply the same investigation set-up on a similar sample in different countries (e.g., based on English common law) in order to verify whether the difference in legislative framework may influence the overall approach to information disclosure.

Further variables may be used to explore associations between organisational characteristics and disclosure of information. Future studies could focus on the type of organisational culture and strategies in place (internal drivers) and the influence of external pressures from stakeholder groups (external drivers). Future research could also focus on the impacts of disclosing environmental and social information online, namely as a complement to formal reports beyond the "one size fits all" reporting approach; and a potential instrument to enhance a two-way communication channel between the organisational and stakeholders through internet-based tools.

Author Contributions: Authors contributed equally to this work.

Funding: Authors would like to acknowledge the support of the research grant SPS Flagship ReIndustrialise Project, financed by EIT Climate KIC supported by EIT, a body of the European Union.

Acknowledgments: Authors would also like to acknowledge the valuable comments provided by three anonymous reviewers on the paper; and support from Lorenzo Cellini, Caterina D'Assergio, Federica Vecchioni, Donato Cutolo, and Joseph Orme-Dawson.

Conflicts of Interest: The authors declare no conflict of interest. 


\section{Appendix A}

Table A1. List of the 69 KPIs used to collect data from the 2008 organisations.

\begin{tabular}{|c|c|c|}
\hline Thematic Area/Indices & & Indicator \\
\hline \multirow{7}{*}{ Environmental certification (EC) } & \multicolumn{2}{|r|}{ Existence of: } \\
\hline & $\mathrm{EC} 1^{\mathrm{c}}$ & ISO 14001 \\
\hline & $\mathrm{EC} 2^{\mathrm{c}}$ & EMAS \\
\hline & $\mathrm{EC} 3^{\mathrm{c}}$ & ISO 50001 \\
\hline & $\mathrm{EC} 4^{\mathrm{c}}$ & Ecolabels (e.g., FSC, Energy star, MSC, EU ecolabel) \\
\hline & $\mathrm{EC} 5^{\mathrm{c}}$ & GOLDPOWER \\
\hline & $\mathrm{EC} 6^{\mathrm{c}}$ & LEED \\
\hline \multirow{7}{*}{ Social certification (SC) } & \multicolumn{2}{|r|}{ Existence of: } \\
\hline & $\mathrm{SC} 1^{\mathrm{c}}$ & SA 8000 \\
\hline & $\mathrm{SC} 2^{\mathrm{c}}$ & ISO 26000 \\
\hline & $\mathrm{SC} 3^{\mathrm{c}}$ & OHSAS 18001 \\
\hline & $\mathrm{SC} 4^{\mathrm{c}}$ & IFS \\
\hline & $\mathrm{SC} 5^{\mathrm{c}}$ & ISO 22005 \\
\hline & $\mathrm{SC} 6^{\mathrm{c}}$ & ISO 22000 \\
\hline \multirow{5}{*}{ Business model (BM) } & & Development of products or technologies for: \\
\hline & $\mathrm{BM} 1^{\mathrm{c}}$ & Renewable energy \\
\hline & $\mathrm{BM} 2^{\mathrm{c}}$ & Water treatment, purification or to improve efficiency on water use \\
\hline & $\mathrm{BM}^{\mathrm{c}}$ & Report or communication of initiatives to produce or promote organic food and other products \\
\hline & $\mathrm{BM} 4^{\mathrm{c}}$ & Relation with nuclear energy industry (e.g., construction of reactors, production of nuclear energy) \\
\hline \multicolumn{3}{|r|}{ Existence of: } \\
\hline \multirow{8}{*}{ Energy (EE) } & EE1 & Eolic generator \\
\hline & EE2 & Wind or water mill \\
\hline & EE3 & Co-generation plant \\
\hline & EE4 & Photovoltaic panels \\
\hline & EE5 & Energy-saving lamps \\
\hline & EE6 & Building envelope thermal insulation \\
\hline & EE7 & Green roof \\
\hline & EE8 & Actions planned for the next 5 years \\
\hline
\end{tabular}


Table A1. Cont.

\begin{tabular}{|c|c|c|}
\hline Thematic Area/Indices & & Indicator \\
\hline \multirow{11}{*}{ Corporate Social Responsibility (CSR) } & CSR1 * & Statement or policy of equal opportunities \\
\hline & CSR2 * & Ethical code \\
\hline & CSR3 * & Development of training policies/training for employees (beyond mandatory regulation) \\
\hline & CSR4 * & Risk analysis policy for employees' protection in the working environment \\
\hline & CSR5 & Sustainability/environmental report \\
\hline & CSR6 & Day-care service/flexible working hours \\
\hline & CSR7 & Environmental impact assessment studies \\
\hline & CSR8 & External audit for CSR/Health and Safety/sustainability report \\
\hline & CSR9 & $\begin{array}{l}\text { Appropriate internal communication tools (e.g., whistle-blower, ombudsman, suggestion box, hotline, } \\
\text { newsletter, intranet) to ensure better environmental management }\end{array}$ \\
\hline & CSR10 & $\begin{array}{l}\text { Partnership or initiatives with specialized NGOs/industry organisations/governmental or } \\
\text { supra-governmental organisations focused on improving environmental issues }\end{array}$ \\
\hline & CSR11 & Actions planned for the next 5 years \\
\hline \multirow{7}{*}{ Emissions (EM) } & & Monitor of environmental impacts caused by: \\
\hline & EI1 * & Air emissions \\
\hline & $\mathrm{EI} 2 *$ & Land emissions and spills \\
\hline & $\mathrm{EI} 3$ * & Water emissions \\
\hline & EI4 * & Identification of specific objectives to reduce emissions \\
\hline & EI5 & Information disclosed about initiatives for environment restoration \\
\hline & EI6 & Quantitative information provided to support the information disclosed \\
\hline \multirow{7}{*}{ Supply chain (SP) } & SP1 * & Environmental and social criteria to select suppliers \\
\hline & $\mathrm{SP} 2 *$ & Policy to reduce environmental impacts of the supply chain \\
\hline & $\mathrm{SP} 3 *$ & $\begin{array}{l}\text { Description of the origin of the resources used and the origin of production (product transparency and } \\
\text { "Made in Italy") }\end{array}$ \\
\hline & $\mathrm{SP} 4$ * & Communication policies to inform consumers about the sustainability of the products \\
\hline & SP5 & Initiatives to reduce the environmental impact of transportation used for staff \\
\hline & SP6 & Initiatives to reduce the environmental impact of the transportation of products \\
\hline & SP7 & Initiatives to return used/old products \\
\hline
\end{tabular}


Table A1. Cont.

\begin{tabular}{|c|c|c|}
\hline Thematic Area/Indices & & Indicator \\
\hline \multirow{10}{*}{$\begin{array}{l}\text { Waste Management (WM) \& Circular economy } \\
\qquad \text { (CE) }\end{array}$} & WM1 * & Separated waste collection \\
\hline & WM2 * & Separated waste collection description \\
\hline & WM3 & Reference to regulation \\
\hline & $\mathrm{CE} 1 *$ & Use of recycled materials in the manufacturing of the products \\
\hline & $\mathrm{CE} 2 *$ & Flawed product recycling \\
\hline & CE3 & Waste as energy/heat source \\
\hline & CE4 & Biodegradable packaging material \\
\hline & CE5 & Packaging recovery and reuse \\
\hline & WM3/CE6 & Actions planned for the next 5 years \\
\hline & WM4/CE7 & Quantitative information provided to support the information disclosed \\
\hline \multirow{5}{*}{ Water (WA) } & WA1 * & Treatment/purification/capture plant of wastewater \\
\hline & WA2 $*$ & Treatment/purification/capture plant of rainwater \\
\hline & WA3 * & Amount of re-used water \\
\hline & WA4 & Actions planned for the next 5 years \\
\hline & WA5 & Quantitative information provided to support the information disclosed \\
\hline \multirow{5}{*}{ Product innovation (PD) } & PD1 * & $\begin{array}{c}\text { Description of initiatives in place to reduce the energy footprint of products during the use phase } \\
\text { Environmental product innovation policy/initiative on: }\end{array}$ \\
\hline & $\mathrm{PD} 2 *$ & Eco-design \\
\hline & PD3 * & Life-cycle assessment \\
\hline & PD4 & Dematerialisation \\
\hline & $\begin{array}{l}\text { PD5 } \\
\text { PD6 }\end{array}$ & $\begin{array}{c}\text { Description of new product techniques to minimize environmental impact (all emissions) during the } \\
\text { production process } \\
\text { Development of goods and services that improve energy efficiency of buildings }\end{array}$ \\
\hline
\end{tabular}

Note: ${ }^{*}$ KPIs considered from the factor analysis; ${ }^{c}$ KPIs used as contingent variables. 


\section{Appendix B}

Table A2. Correlation coefficients of organisational characteristics and indices.

\begin{tabular}{|c|c|c|c|c|c|c|c|c|c|c|c|c|c|c|}
\hline & & & 1 & 2 & 3 & 4 & 5 & 6 & 7 & 8 & 9 & 10 & 11 & 12 \\
\hline Organisationa & 1 & Revenue & 1 & & & & & & & & & & & \\
\hline Characteristics & 2 & N. employees & 0.2982 & 1 & & & & & & & & & & \\
\hline \multirow{3}{*}{$\begin{array}{l}\text { Contingent } \\
\text { Variables }\end{array}$} & 3 & Environmental certifications & 0.1765 & 0.2787 & 1 & & & & & & & & & \\
\hline & 4 & Social certifications & 0.2321 & 0.1743 & 0.4763 & 1 & & & & & & & & \\
\hline & 5 & Business model & 0.1195 & 0.0842 & 0.1555 & 0.2327 & 1 & & & & & & & \\
\hline \multirow{7}{*}{$\begin{array}{c}\text { Thematic } \\
\text { Areas }\end{array}$} & 6 & CSR & 0.2220 & 0.3180 & 0.4571 & 0.3790 & 0.1673 & 1 & & & & & & \\
\hline & 7 & Emissions & 0.2084 & 0.2136 & 0.4361 & 0.2917 & 0.1860 & 0.4468 & 1 & & & & & \\
\hline & 8 & Supply chain & 0.2218 & 0.1549 & 0.3493 & 0.4105 & 0.2791 & 0.4031 & 0.4425 & 1 & & & & \\
\hline & 9 & Waste Management & 0.0965 & 0.1422 & 0.3180 & 0.2090 & 0.0972 & 0.3095 & 0.4478 & 0.3359 & 1 & & & \\
\hline & 10 & Circular economy & 0.1251 & 0.1317 & 0.2623 & 0.1197 & 0.0627 & 0.2393 & 0.3947 & 0.2855 & 0.3234 & 1 & & \\
\hline & 11 & Water & 0.1807 & 0.1339 & 0.3300 & 0.2213 & 0.1671 & 0.2784 & 0.4682 & 0.3475 & 0.4170 & 0.3455 & 1 & \\
\hline & 12 & Product innovation & 0.1709 & 0.1844 & 0.2997 & 0.2085 & 0.2287 & 0.2579 & 0.3746 & 0.3433 & 0.2000 & 0.2862 & 0.2800 & 1 \\
\hline
\end{tabular}

Note: All coefficients significant for $p<0.01$. 


\section{References}

1. Siew, R.Y.J. A review of corporate sustainability reporting tools (SRTs). J. Environ. Manag. 2015, 164, $180-195$. [CrossRef] [PubMed]

2. Domingues, A.R.; Lozano, R.; Ceulemans, K.; Ramos, T.B. Sustainability reporting in public sector organisations: Exploring the relation between the reporting process and organisational change management for sustainability. J. Environ. Manag. 2017, 192, 292-301. [CrossRef] [PubMed]

3. Farneti, F.; Guthrie, J. Sustainability reporting by Australian public sector organisations: Why they report. Acc. Forum 2009, 33, 89-98. [CrossRef]

4. Directive 2014/95/EU of the European Parliament and of the Council Directive 2014/95/EU of the European Parliament and of the Council of 22 October 2014 Amending Directive 2013/34/EU as Regards Disclosure of Non-Financial and Diversity Information by Certain Large Undertakings and Groups; EU: Brussels, Belgium, 2014.

5. Haddock-Fraser, J. The Role of the News Media in Influencing Corporate Environmental Sustainable Development: An Alternative Methodology to Assess Stakeholder Engagement. Corp. Soc. Responsib. Environ. Manag. 2012, 19, 327-342. [CrossRef]

6. Lodhia, S.; Stone, G. Integrated Reporting in an Internet and Social Media Communication Environment: Conceptual Insights. Aust. Acc. Rev. 2017, 27, 17-33. [CrossRef]

7. Isenmann, R.; Bey, C.; Welter, M. Online reporting for sustainability issues. Bus. Strategy Environ. 2007, 16, 487-501. [CrossRef]

8. de Lancer Julnes, P. Performance Measurement Beyond Instrumental Use. In Performance Information in the Public Sector How It Is Used; Van Dooren, W., Van de Walle, S., Eds.; Palgrave Macmillan: Basingstoke, UK, 2011.

9. Isenmann, R.; Ki-Cheol, K. Interactive Sustainability Reporting: Developing Clear Target Group Tailoring and Stimulating Stakeholder Dialogue. In Sustainability Accounting and Reporting; Schaltegger, S., Bennett, M., Burritt, R., Eds.; Springer: Berlin/Heidelberg, Germany, 2006; pp. 533-537.

10. Manetti, G.; Bellucci, M.; Bagnoli, L. Stakeholder Engagement and Public Information Through Social Media: A Study of Canadian and American Public Transportation Agencies. Am. Rev. Public Adm. 2016, 47, 991-1009. [CrossRef]

11. Deegan, C. Organisational Legitimacy as a Motive for Sustainability Reporting. In Sustainability Accounting and Accountability; Unerman, J., Bebbington, J., O’Dwyer, B., Eds.; Routledge (Taylor \& Francis Group): London, UK, 2007; pp. 127-149.

12. Cormier, D.; Magnan, M. The Economic Relevance of Environmental Disclosure and its Impact on Corporate Legitimacy: An Empirical Investigation. Bus. Strategy Environ. 2013, 24, 431-450. [CrossRef]

13. Bebbington, J.; Higgins, C.; Frame, B. Initiating sustainable development reporting: Evidence from New Zealand. Acc. Audit. Account. J. 2009, 22, 588-625. [CrossRef]

14. Herzig, C.; Schaltegger, S. Corporate sustainability reporting: An overview. In Sustainability Accounting and Reporting; Schaltegger, S., Bennett, M., Burritt, R., Eds.; Springer: Berlin/Heidelberg, Germany, 2006; pp. 301-324.

15. Amran, A.; Ooi, S.K. Sustainability reporting: Meeting stakeholder demands. Strateg. Dir. 2014, 30, 38-41. [CrossRef]

16. Lozano, R.; Nummert, B.; Ceulemans, K. Elucidating the relationship between Sustainability Reporting and Organisational Change Management for Sustainability. J. Clean. Prod. 2016, 125, 168-188. [CrossRef]

17. Ceulemans, K.; Lozano, R.; Alonso-Almeida, M. Sustainability Reporting in Higher Education: Interconnecting the Reporting Process and Organisational Change Management for Sustainability. Sustainability 2015, 7, 8881-8903. [CrossRef]

18. Mura, M.; Longo, M.; Micheli, P.; Bolzani, D. The Evolution of Sustainability Measurement Research. Int. J. Manag. Rev. 2018, 20, 661-695. [CrossRef]

19. Dowling, J.; Pfeffer, J. Organizational Legitimacy: Social Values and Organizational Behavior. Pac. Sociol. Rev. 1975, 18, 122-136. [CrossRef]

20. DiMaggio, P.J.; Powell, W.W. The Iron Cage Revisited: Institutional Isomorphism and Collective Rationality in Organizational Fields. Am. Sociol. Rev. 1983, 48, 147-160. [CrossRef]

21. da Silva Monteiro, S.M.; Aibar-Guzmán, B. Determinants of environmental disclosure in the annual reports of large companies operating in Portugal. Corp. Soc. Responsib. Environ. Manag. 2010, 17, 185-204. [CrossRef] 
22. Castelo Branco, M.; Lima Rodrigues, L. Communication of corporate social responsibility by Portuguese banks. Corp. Commun. Int. J. 2006, 11, 232-248. [CrossRef]

23. Tagesson, T.; Blank, V.; Broberg, P.; Collin, S.-O. What explains the extent and content of social and environmental disclosures on corporate websites: A study of social and environmental reporting in Swedish listed corporations. Corp. Soc. Responsib. Environ. Manag. 2009, 16, 352-364. [CrossRef]

24. Cormier, D.; Magnan, M.; Van Velthoven, B. Environmental disclosure quality in large German companies: Economic incentives, public pressures or institutional conditions? Eur. Acc. Rev. 2005, 14, 3-39. [CrossRef]

25. Gallego-Alvarez, I.; Ortas, E.; Vicente-Villardón, J.L.; Álvarez Etxeberria, I. Institutional Constraints, Stakeholder Pressure and Corporate Environmental Reporting Policies. Bus. Strategy Environ. 2017, 26, 807-825. [CrossRef]

26. Schaltegger, S.; Hörisch, J.; Freeman, R.E. Business Cases for Sustainability: A Stakeholder Theory Perspective. Org. Environ. 2017, 1-22. [CrossRef]

27. Lüdeke-Freund, F.; Carroux, S.; Joyce, A.; Massa, L.; Breuer, H. The sustainable business model pattern taxonomy -45 patterns to support sustainability-oriented business model innovation. Sustain. Prod. Consum. 2018, 15, 145-162. [CrossRef]

28. Bocken, N.M.P.; Short, S.W.; Rana, P.; Evans, S. A literature and practice review to develop sustainable business model archetypes. J. Clean. Prod. 2014, 65, 42-56. [CrossRef]

29. Allee, V. Reconfiguring the value network. J. Bus. Strategy 2000, 21, 36-39. [CrossRef]

30. Rosati, F.; Faria, L.G.D. Business contribution to the Sustainable Development Agenda: Organizational factors related to early adoption of SDG reporting. Corp. Soc. Responsib. Environ. Manag. 2019, 26, 588-597. [CrossRef]

31. Del Mar Alonso-Almeida, M.; Llach, J.; Marimon, F. A Closer Look at the "Global Reporting Initiative" Sustainability Reporting as a Tool to Implement Environmental and Social Policies: A Worldwide Sector Analysis. Corp. Soc. Responsib. Environ. Manag. 2013, 21, 318-335. [CrossRef]

32. De Villiers, C.; van Staden, C.J. Where firms choose to disclose voluntary environmental information. J. Acc. Public Policy 2011, 30, 504-525. [CrossRef]

33. Tang, S.; Demeritt, D. Climate Change and Mandatory Carbon Reporting: Impacts on Business Process and Performance. Bus. Strategy Environ. 2018, 27, 437-455. [CrossRef]

34. Hörisch, J.; Freeman, R.E.; Schaltegger, S. Applying Stakeholder Theory in Sustainability Management. Org. Environ. 2014, 27, 328-346. [CrossRef]

35. Elkington, J. Towards the Sustainable Corporation: Win-Win-Win Business Strategies for Sustainable Development. Calif. Manag. Rev. 1994, 36, 90-101. [CrossRef]

36. De Villiers, C. Stakeholder Requirements for Sustainability Reporting. In Sustainability Accounting and Accountability; De Villiers, C., Maroun, W., Eds.; Routledge, Taylor \& Francis Group: London, UK, 2018.

37. Hahn, R.; Kühnen, M. Determinants of sustainability reporting: A review of results, trends, theory, and opportunities in an expanding field of research. J. Clean. Prod. 2013, 59, 5-21. [CrossRef]

38. Meyer, J.W.; Rowan, B. Institutionalized Organizations: Formal Structure as Myth and Ceremony. Am. J. Sociol. 1977, 83, 340-363. [CrossRef]

39. Herremans, I.M.; Herschovis, M.S.; Bertels, S. Leaders and Laggards: The Influence of Competing Logics on Corporate Environmental Action. J. Bus. Ethics 2009, 89, 449-472. [CrossRef]

40. Roca, L.C.; Searcy, C. An analysis of indicators disclosed in corporate sustainability reports. J. Clean. Prod. 2012, 20, 103-118. [CrossRef]

41. Searcy, C.; Elkhawas, D. Corporate sustainability ratings: An investigation into how corporations use the Dow Jones Sustainability Index. J. Clean. Prod. 2012, 35, 79-92. [CrossRef]

42. Daddi, T.; Todaro, N.M.; De Giacomo, M.R.; Frey, M. A Systematic Review of the Use of Organization and Management Theories in Climate Change Studies. Bus. Strategy Environ. 2018, 27, 456-474. [CrossRef]

43. van Dijk, B. Aida: Italian Company Information and Business Intelligence. Available online: https://www.bvdinfo.com/en-apac/our-products/company-information/national-products/aida (accessed on 26 February 2018).

44. OECD. OECD Regions and Cities at a Glance 2018; OECD Publishing: Paris, France, 2018.

45. Eurostat. Gross Domestic Product (GDP) at Current Market Prices by NUTS II Regions. Available online: http://appsso.eurostat.ec.europa.eu/nui/show.do?dataset=nama_10r_2gdp\&lang=en (accessed on 16 November 2018). 
46. Regione Emilia-Romagna, Servizio Statistica e Informazione Geografica. Le Specializzazioni Produttive Regionali Attraverso I Censimenti Industria e Servizi 2001 e 2011 (Regional Production Census Industry and Services 2001 and 2011). Available online: http://statistica.regione.emilia-romagna.it/allegati/pubbl/2014/lespecializzazioni-produttive-regionali-attraverso-i-censimenti-industria-e-servizi-2001-e-2011 (accessed on 16 November 2018).

47. Baines, T.S.; Lightfoot, H.W.; Evans, S.; Neely, A.; Greenough, R.; Peppard, J.; Roy, R.; Shehab, E.; Braganza, A.; Tiwari, A.; et al. State-of-the-art in product-service systems. Proc. Inst. Mech. Eng. Part B J. Eng. Manuf. 2007, 221, 1543-1552. [CrossRef]

48. Kowalkowski, C.; Gebaue, C.; Oliva, R. Service growth in product firms: Past, present, and future. Ind. Mark. Manag. 2017, 60, 82-88. [CrossRef]

49. Hair, J.F., Jr.; Black, W.C.; Babin, B.J.; Anderson, R.E. Multivariate Data Analysis, 7th ed.; Pearson: London, UK, 2004.

50. Gangi, F.; Meles, A.; Monferrà, S.; Mustilli, M. Does corporate social responsibility help the survivorship of SMEs and large firms? Glob. Finance J. 2018, in press. [CrossRef]

51. Guimarães-Costa, N.; e Cunha, M.P. The atrium effect of website openness on the communication of corporate social responsibility. Corp. Soc. Responsib. Environ. Manag. 2008, 15, 43-51. [CrossRef]

52. Kraft, M.E.; Stephan, M.; Abel, T.D. Coming Clean: Information Disclosure and Environmental Performance; The MIT Press: Cambridge, MA, USA, 2011.

53. Semenova, N.; Hassel, L.G.; Nilsson, H. The value relevance of environmental and social performance: Evidence from Swedish SIX 300 companies. Liiketal. Aikak. 2010, 3, 265-292.

54. Darnall, N.; Henriques, I.; Sadorsky, P. Adopting Proactive Environmental Strategy: The Influence of Stakeholders and Firm Size. J. Manag. Stud. 2010, 47, 1072-1094. [CrossRef]

55. Schaltegger, S.; Burritt, R. Business Cases and Corporate Engagement with Sustainability: Differentiating Ethical Motivations. J. Bus. Ethics 2015, 147, 241-259. [CrossRef]

56. Manetti, G.; Bellucci, M. The use of social media for engaging stakeholders in sustainability reporting. Acc. Audit. Account. J. 2016, 29, 985-1011. [CrossRef]

57. Ramos, T.B.; Martins, I.P.; Martinho, A.P.; Douglas, C.H.; Painho, M.; Caeiro, S. An open participatory conceptual framework to support State of the Environment and Sustainability Reports. J. Clean. Prod. 2014, 64, 158-172. [CrossRef] 